\title{
METHOD OF DETERMINATION OF PEAR LEAF AREA ON LINEAR MEASUREMENTS BY CALCULATION OF CORRECTION FACTORS AND VARIATION STATISTICS APPROACH
}

\author{
N.S. KISELEVA \\ All-Russian Research Institute of Floriculture And Subtropical Crops, Federal Agency of Scientific Organizations, \\ 2/28, ul. Yana Fabritsiusa, Sochi, 354002 Russia, e-mail nskiselyeva_05@mail.ru, subplod@mail.ru \\ ORCID: Kiseleva N.S. orcid.org/0000-0001-8655-6381 \\ The author declares no conflict of interests \\ Received December 18, 2015
}

\section{Abstract}

Morphological study of foliage in fruit crops are mainly conducted to study photosynthetic activity as related to leaf area. Currently, there are different methods to determine this parameter with varying accuracy. In the paper, we first compared the accuracy of assessing leaf area in pear by two methods based on a relationship between the leaf size (S) and its linear dimensions, the length (L) and the width (W). These ways were the use of a conversion factor (correction coefficient) and the regression analysis. The following 10 pear genotypes of different ripening were involved to measure the leaf linear parameters: Pirus communis L. - varieties Beurre Giffard, Vega (early ripening); varieties Williams, Chernomorskaya Yantarnaya (summer ripening); Beurre Bosk, Rassvet, hybrid № 8520, Nart; Pirus serotina Rehd. - varieties Kilchu and Choo-chen-sok (autumn ripening). The correction by means of conversion factor was based on a similarity of the investigated leaf shape to relevant geometrical figure. Under this model, the leaf area calculation as $S=0.69 \times(\mathrm{LW})$ was the most exact. This formula allows us to fast and exactly estimate the intact leaf size in pear trees and in other fruit crops with the same leaf shape to determine its changes throughout long time without destruction. Under the regression analysis procedure, the independent variables were $\mathrm{L}, \mathrm{W}, \mathrm{L}^{2}, \mathrm{~W}^{2}$, and $\mathrm{LW}$. Of these, the latter (LW) was optimum, resulting in a linear regression equation $\mathrm{Y}=0,922581+0,660898 \times(\mathrm{LW})$ based on which the MS Excel 7.0 program has been developed. This program allows us to find the sum of leaf areas or to determine an individual leaf area. Additionally, we found the indicators of leaf size and shape, and the averages for the sample, and also suggested graphics displaying leaf area. The scale for estimation was developed as a nomogram. Radial diagram with the special scale marked as area units against $\mathrm{L}$ and $\mathrm{W}$ units was also offered to simplify extensive research when more than 50-100 estimations required. Thus, due to close positive correlation between leaf linear dimensions and area, it is possible to practically apply conversion factor and regression equations, including developed nomogram and radial diagram, for calculation of leaf areas with the minimum error under natural conditions. The developed models may be helpful to measure area of oval, ovoid and unlobed leaves in southern fruit crops (e.g. apple, pear, cherry, plum), subtropical crops (citrus, feijoa, persimmon, tea), and ornamental wood bushes and grassy plants used for landscape gardening. Computerized technology promotes acceleration and simplification of the calculations.

Keywords: pear, Pirus communis L., Pirus serotina Rehd., genotype, leaf plate, leaf length, leaf width, leaf area, conversion factor, regression analysis

The investigation of morphological features of the plant, their variability and varietal stability allows obtaining detailed information about the genotype as a whole and its interaction with the environment. The correlation between productivity and the varietal resistance to the main stress factors is unquestionable, but it is influenced by other factors, primarily the activity and the nature of the assimilation apparatus.

A leaf is an organ of a higher plant, functionally designed for photosynthesis, transpiration and gas exchange. Providing the plant with plastic substances and participating in the continuous transport of substances along conductive structures, it plays a multi-functional role in supporting the vital activity, devel- 
opment and adaptation of the plant organism. Among other vegetative organs of the plant, the leaf is the structure most active in the metabolic relation and with diverse morphology [1-3]. Morphological examination of the leaf apparatus of fruit crops is carried out mainly in connection with the study of photosynthetic activity, with one of the metric indices being used, i.e. the area of the leaf blade [4]. Modern computer technology and statistical methods allow to increase the accuracy of the analysis and reveal patterns that could not have been detected earlier due to serious inaccuracy.

Currently, experience has been accumulated in the application of methods which, with varying degrees of accuracy, make it possible to determine the leaf area, such as weight method, planimetric method, method of standards, determination of the area by the specific weight of leaf cutouts, electrographic powder method. Such developments have several significant drawbacks. They are either labour-intensive and inefficient, or their use is associated with the separation of leaves from the plant and the inability to follow-up them. Therefore, more attention is paid to the mathematical method of calculating leaf area by its linear dimensions. Several methods for measuring the area of leaves have been described. Their common advantage consists in deducing on the basis of regression mathematically grounded leaf area formulas for different species and varieties of crops during mass determinations [5-8]. N.Ph. Konyaev applied the linear regression method which allows deriving leaf area formulas for various vegetable crops [9]. The disadvantage of this method is that, if the formulas drawn based on the length and width or just the length of the leaf are equal, the individual deviations of the area are larger in the cases where the formula is drawn based on just the length of the leaf and lesser when it is drawn based on the length and width. To improve accuracy, it is advisable to derive formulas for each variety separately.

V.Ya. Volkov and N.Ph. Selevtsev proposed a series of three mathematical models for determining the area of cucumber leaves based on their length and width at different stages of growth [10]. The length of the leaf in this case is the length of the line of the segment (part) of the leaf blade pattern from the tip to the point perpendicular to the intersection with the line of the pattern along the width of the blade, closer to the leaf petiole. The method is applicable only to the specific shape of the leaf blade, taking into account its growth characteristics. N.S. Robbins и D.M. Pharr applied the multiple regression method, taking into account the characteristics of growth and growing conditions [11]. The length of the cucumber leaf was measured from the tip to the end point of the central vein. However, in this case it is required to derive an individual formula for each variety not only based on the genotype characteristics, but also considering the growth conditions.

A method for determining the area of a strawberry leaf was developed using a special scale based on the methods of variational statistics [12]. Its advantage consists in revealing the correlation between the leaf area defined by the planimeter and its parameters. This correlation is expressed by an equation and is used to calculate the area of the strawberry leaf along the central vein, and also to obtain a scale for practical use. The disadvantage of the method is that for calculating the error of estimate not more than $5 \%$, it is required to calculate the leaf area in the range from 15 to $220 \mathrm{~cm}^{2}$.

In this paper, for the first time we used two methods for estimating the area of the leaf surface for the pear crop, such as based on the scaling ratio and by means of regression equations relating the leaf area with its linear dimensions (length and width).

The objective of the study is to determine the correction factor and obtain a regression model for calculating the leaf area without separating it from 
the plant in different pear varieties with a minimum possible error.

Techniques. Investigations were carried out at the collection site (planted in 1998) of the All-Russian Research Institute of Floriculture and Subtropical Crops in 2001-2004. The leaf biometric parameters were studied on 10 varieties of pear of different maturation periods: Pirus communis L. - Beurré Giffard, Vega (early summer ripening); Williams, Chernomorskaya Yantarnaya (summer ripening); Beurré Bosk, Rassvet, hybrid № 8520, Nart; Pirus serotina Rehd. Kilchu and Choo-chen-sok (autumn ripening). Leaves were taken from the middle part of the crown for each variety, 10 pcs. each in 3 replicates [14]. Each leaf was measured using a ruler along the central vein and width at the widest position, the leaf area was determined by planimetry using palettes $(15 \times 10 \mathrm{~cm}$ film plates with $0.5 \mathrm{~cm}^{2}$ squares drawn).

Data on the length and width of the leaf blade was used to determine the conversion factor and calculate the area based on the methods of variation statistics [15-22]. The relationship between the actual area of the leaf and its parameters was expressed with an equation used for the theoretical calculation of the area of the pear leaf. When constructing the regression model, the following parameters were used as regressors: length $(\mathrm{L})$, square length $\left(\mathrm{L}^{2}\right)$, width $(\mathrm{W})$, square width $\left(\mathrm{W}^{2}\right)$ and $\mathrm{LW}$.

The data processing was performed by the correlation analysis and regression analysis, descriptive statistics, using the Statistica for Windows 5.5 [23] software package and Microsoft Excel 7.0.

Results. The method for determining the area of the leaf using the estimated coefficient is based on the correlation between the shape of the leaf (as an indicator of the genotype feature) and a geometrical figure describing it (elliptical, narrow or back-ovoid, oval, round, lancet-shaped) [24, 25]. The variety of shapes of leaf blades suggests a wide variation in the choice of linear dimensions. In most cases, two indicators are used, such as the length and the width, which have a high correlation (0.98) with the area of the leaf surface [26]. Having determined the shape of the figure which fits the leaf, one can calculate the coefficient between its actual area, measured by the direct (planimetrical) method, and the area of the figure [27-29].

The coefficient is defined as the ratio of the actual area to the area of the rectangle with $\mathrm{x}$ and $\mathrm{y}$ sides:

$$
\mathrm{K}=\mathrm{S} / \mathrm{L} \times \mathrm{W},
$$

where $\mathrm{K}$ is the coefficient (dimensionless quantity), $\mathrm{L}$ is leaf length $(\mathrm{cm}), \mathrm{W}$ is the leaf width $(\mathrm{cm}), \mathrm{S}$ is the leaf area $\left(\mathrm{cm}^{2}\right)$ determined by a direct method.

To simplify the coefficient calculation, one can calculate it by the length or width:

$$
\begin{aligned}
& \mathrm{K}=\mathrm{S} / \mathrm{L}^{2}, \\
& \mathrm{~K}=\mathrm{S} / \mathrm{W}^{2} .
\end{aligned}
$$

The method of the calculated coefficient does not require complicated computer equipment, it can be easily used in the field. In addition, long-term observations are feasible in this case, for example, to determine changes in the leaf area during plant development from the initial stages to its dieback.

Using the formulas (1), (2), (3), we determined three variants of the estimated coefficient, i.e. $K_{1}, K_{2}, K_{3}$. For each of them, three samples of 100 values were obtained, which were subjected to statistical processing with the calculation of the mean $(X)$ and the coefficient of variation $(C v, \%)$, which varied from 1.18 (for $\mathrm{K}_{1}$ ) to 2.57 (for $\mathrm{K}_{2}$ ). The smaller was the coefficient of variation, the smaller were the deviations of each value of the sample from the calculated mean. The analysis showed a slight difference (0.11-0.65\%) when applying for- 
mulas with the estimated coefficient for different varieties. With calculations using one formula in 10 pear varieties, the minimum error was $0.1 \%$. The most accurate way to determine the area of pear leaves using the estimated coefficients is to calculate it based on LW using the following formula: $\mathrm{S}=0,69 \times(\mathrm{LW})$. This formula can be used to quickly calculate the area of leaves of pear and other fruit crops with a similar shape of the leaf blade. The proposed method allows to observe the changes in the leaf area over a long period and determine the photosynthesis rate (the amount of organic matter accumulated by leaves over a certain period of time).

The search for an optimal mathematical model by variational statistics methods for the theoretical determination of the leaf area was carried out by linear and multiple regression analysis. The tests showed that for different pear varieties the inclusion of the width in the regression model provided a more accurate calculation of the leaf area $\left(\mathrm{R}^{2}=0.98\right)$. A similar method of estimating the area of a leaf is required to study the relationship between the area of the leaf blade and the growth of the plant. The area of one leaf or multiple leaves of one plant, calculated using the formulas, can exactly match or slightly or substantially deviate from the values obtained with a planimeter. This is explained by individual plant differences and age-related changes in the leaf shape. The closer the points are relative to the line of the regression curve, the lesser are the deviations from the actual area.

The formulas can be drawn both from the length and width measurements and the measurement of just the length of the leaf. Based on their equivalence and accuracy, the individual deviations of the area in our tests turned out to be greater when the formula was derived from the length of the leaf and lesser - from the length and width. It was reasonable to derive formulas for each variety separately, because cross replacement of formulas for different varieties decreased the accuracy of determining the area. If a minimum error was observed for calculating the area of a leaf using one formula for several varieties, then this formula could be considered a common one for the pear crop. The analysis of the obtained data established a close positive correlation between the parameters of the length, width and area of the leaf blade, which allowed to calculate the equations of the linear and curvelinear (parabolic) regression of the leaf area of the pear.

The selection model needed a balance between the accuracy of calculation and a variability factor (the smallest number of variables needed for the calculation). Having estimated the determination coefficient $\left(\mathrm{R}^{2}\right)$, Fisher's $F$-test, the mean square error $(\mathrm{mS})$ for each regression calculation, we found several equations suitable for calculating the area of the pear leaf (see Table). After step-bystep selection, the most accurate was the following equation: $\mathrm{Y}=-6.613161-$ $-0.272064 \times(\mathrm{LW})+4.9738 \times \mathrm{W}\left(\mathrm{R}^{2}=97.91\right)$ at $\mathrm{p}<0.01$.

The equation $\mathrm{Y}=0.922581+0.660898 \times(\mathrm{LW})$ was less accurate $\left(\mathrm{R}^{2}=97.13 \%\right)$, but since the correlation coefficient between the area and the product of the length of the leaf and its width turned out to be high $(r=98.5)$, we applied this mathematical model of linear regression.

Regression models describing the dependence of the leaf area on its length and width in pear varieties

\begin{tabular}{l|r|r|r}
\hline \multicolumn{1}{c|}{ Model } & $\mathrm{R}^{2}$ & $\mathrm{mS}$ & $F$ \\
\hline $\begin{array}{l}\text { Length-based model: } \\
\mathrm{Y}=-32.7338+6.89464 \times \mathrm{L}\end{array}$ & 87.21 & 59.4 & 191.01 \\
$\begin{array}{l}\text { Width-based model: } \\
\mathrm{Y}=-11.565+8.37592 \times \mathrm{W}\end{array}$ & 97.54 & 66.44 & 1111.15 \\
Model based on the product of length and width: & & & \\
$\mathrm{Y}=0.922581+0.660898 \times(\mathrm{WW})$ & 97.13 & 66.16 & 950.95
\end{tabular}


Model based on the square length and width:

$\mathrm{Y}=-4.87168+0.426423 \times \mathrm{L}^{2}$

$\begin{array}{lll}87.67 & 59.72 & 199.15\end{array}$

$\mathrm{Y}=5.65063+1.01831 \times \mathrm{W}^{2}$

$\begin{array}{lrr}98.13 & 66.84 & 1473.21\end{array}$

Model based only on the length and its square:

$\mathrm{Y}=434.525-108.44 \times \mathrm{L}+7.1152 \times\left(\mathrm{L}^{2}\right)$

$91.16 \quad 41.05 \quad 139.22$

Model based on the length, width, their squares:

$\mathrm{Y}=-6.613161-0.272064 \times(\mathrm{LW})+4.9738 \times \mathrm{W}$

$97.91 \quad 33.34$

$99.09 \quad 22.15$

$\mathrm{Y}=267.743+4.32894 \times \mathrm{L}^{2}-68.7042 \times \mathrm{L}+6.70968 \times \mathrm{W}$

$98.89 \quad 22.45$

$\mathrm{Y}=271.486+0.773545 \times(\mathrm{LW})+4.01169 \times \mathrm{L}^{2}-66.374 \times \mathrm{L}$

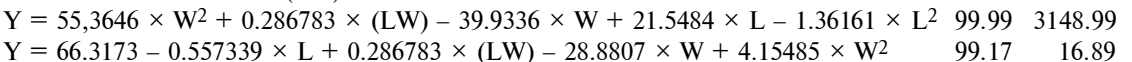

$\mathrm{N}$ o t e. $\mathrm{Y}-$ the area, $\mathrm{L}-$ length, $\mathrm{W}-$ width; $\mathrm{R}^{2}-$ the determination coefficient; $\mathrm{mS}-$ mean sum of squares of the regression; $F-$ the value of the Fisher test.

The analysis of the diagrams (Fig.) and summing of the obtained data showed that regression models with a single LW measurement can serve to accurately calculate the leaf area in different pear varieties.

A

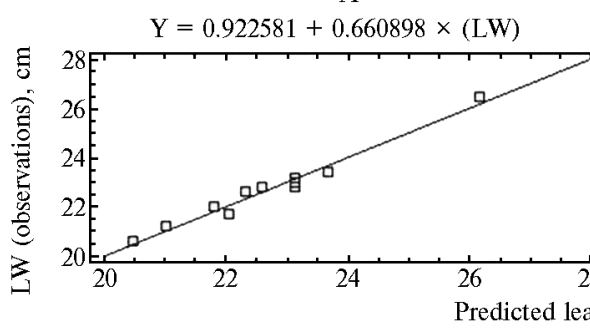
$\mathrm{Y}=-6.613161-0.272064 \times(\mathrm{LW})+4,9738 \times \mathrm{W}$

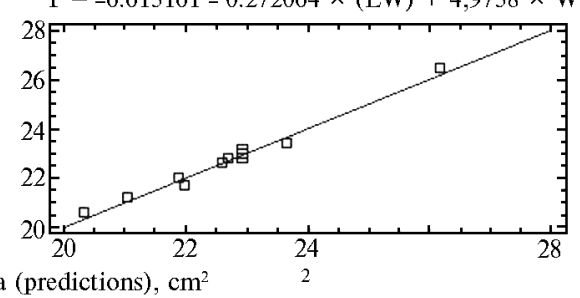

Diagrams representing the equations of linear (A) and multiple (B) regression for models of calculating the area of a pear leaf based on its length (L) and width (W).

The values of Fisher's $F$-test derived from the analysis of variance, indicate that the deviation from linearity was due to random selective variation and the zero hypothesis about the absence of a linear relationship was rejected. As $\mathrm{F}_{\mathrm{f}}>\mathrm{F}_{\mathrm{st}}$, there was a significant difference between varieties at $1.0 \%$. All models were statistically significant $(\mathrm{p}<0.01)$, the significance level for the interaction of traits was $99.0 \%$. Based on the resulting regression equation, we developed a program for calculating the leaf area in MS Excel 7.0. The method we proposed for calculating the area of pear leaves makes it possible to construct a scale by calibrating it in units of area. To accomplish this, the equation obtained must be solved with respect to L and W. Applying over the scale a pear leaf along its length with adjustment for its width, we derive the leaf area. To speed up and simplify the procedure with 50-100 measurements taken, a radial diagram can be built. The arcs are drawn over the diagram through each $1 \mathrm{~cm}$ of the leaf length. To determine the area, one should attach a leaf with the central vein to the start of the diagram $(0$ point) and, having determined the length, adjust for the width (or, using the biometric data previously obtained, calculate the area by the diagram).

The developed methods can be used to determine the area of oval, ovoid and non-dissected leaves in southern fruit crops (apple, pear, cherry, plum) and subtropical crops (citrus, feijoa, persimmon, tea), woody, shrubby and herbaceous plants.

Therefore, the most accurate way to determine the area of the pear leaves is a calculation based on a single measurement of the LW. A close positive relation between the length and width of the leaf blade makes it possible to accurately calculate in the field the leaf areas for different pear varieties using the methods of the estimated coefficient, regression equation, nomogram and radial diagram with a minimum error. Computer technology allows to speed up and simplify these calculations. 


\section{R E F E R E N C ES}

1. Forest Ecology: recent advances in rlant ecology. A.G. Van der Valk. Springer, 2009 (doi: 10.1007/978-90-481-2795-5).

2. Gib s o n J.P., Gib s o n T.R. Plant ecology. NY, 2006.

3. Schulze E.-D., B e c k E., Mulle r-Hohenstein K. Plant ecology. Springer, Berlin, 2005.

4. Fulg a I.G. Izuchenie fotosinteticheskoi poverkhnosti rastenii [Study of photosynthetic plant area]. Kishinev, 1961 (in Russ.).

5. Ackley W., C randall P., Rus s e 1 T. The use of linear measurements in estimating leaf areas. Proc. Amer. Soc. Hort. Sci., 1958, 72: 326-330.

6. Blanco F., Folegatti M. A new method for estimating the leaf area index of cucumber and tomato plants. Hortic. Bras., 2003, 21(4): 666-669 (doi: 10.1590/S0102-05362003000400019).

7. Dryannykh N.M., Ko rs akova T.I., P e tre nko E.S. V sbornike: Prostranstvennovremennaya struktura lesnykh biogeotsenozov [Spatiotemporal structure of forest ecosystems]. Novosibirsk, 1981: 76-81 (in Russ.).

8. U t k i n A.I., E rmolova L.S., U t k i na I.A. Ploshchad' poverkhnosti lesnykh rastenii: sushchnost', parametry, ispol'zovanie [Area of forest plants - essence, prameters, use]. Moscow, 2008 (in Russ.).

9. K o n y a e v N.F. Doklady VASKHNIL, 1970, 9: 43-46 (in Russ.).

10. V o 1 k o v V.Ya., S e l e v t s e v V.F. Fiziologiya rastenii, 1959, 6(5): 627-630 (in Russ.).

11. Robbins N.S., Pharr D.M. Leaf area prediction models for cucumber from linear measurements. Hortic. Sci., 1987, 22(6): 1264-1266.

12. Filo n ov V.B. Materialy II nauchnoi konferentsii molodykh uchenykh-sadovodov Kazakhstana «Intensifikatsiya plodovodstva $i$ vinogradarstva» [Proc. II Conf. «The intensification of horticulture and viticulture»]. Alma-Ata, 1974: 91-93 (in Russ.).

13. K i s e l e v a N.S Materialy nauchno-prakticheskoi konferentsii «Subtropicheskoe sadovodstvo Rossii $i$ osnovnye napravleniya nauchnogo obespecheniya ego razvitiya do 2010 goda» [Proc. Conf. «Subtropical horticulture in Russia and the basic aspects of scientific support for its development until 2010»]. Sochi, 2004: 145-148 (in Russ.).

14. Programma $i$ metodika sortoizucheniya plodovykh, yagodnykh $i$ orekhoplodnykh kul'tur /Pod redaktsiei E.N. Sedova, T.P. Ogol'tsovoi [Program and methods of studying varieties of fruit, berry and nut crops. E.N. Sedov, T.P. Ogol'tsova (eds.)]. Orel, 1999 (in Russ.).

15. Pros u n o V.M., K o z e l A.I. Sel'skokhozyaistvennaya biologiya [Agricultural Biology], 1979, 14(26): 232-234 (in Russ.).

16. $\mathrm{N}$ i k o l e $\mathrm{n}$ k o V.V., K o t o v S.F. Uchenye zapiski Tavricheskogo natsional'nogo universiteta imeni V.I. Vernadskogo. Seriya Ekosistemy, ikh optimizatsiya i okhrana, 2010, 2: 99-105 (in Russ.).

17. Fedoryako N.I. Morfobiologicheskie osobennosti i matematicheskaya interpretatsiya parametrov list'ev sortov zemlyaniki v usloviyakh TSCHR. Avtoreferat kandidatskoi dissertatsii [Morphobiological characterization of strawberry leaves and its mathematical interpretation for different varieties under the conditions of Central Russia. PhD Thesis]. Michurinsk, 2004 (in Russ.).

18. G a miely S., Randle W.M., Miks H.A., S mittle D.A. A rapid and nondestructive method for estimating leaf area of onions. Hortic. Sci., 1991, 26(2): 206-210.

19. B a k h shandeh E., K a m k a r B., T s i l t a s J.T. Application of linear models for estimation of leaf area in soybean [Glycine $\max (\mathrm{L}$.$) Merr]. Photosynthetica, 2011, 49: 405$ (doi: 10.1007/s11099-011-0048-5).

20. Kandiannan K., K a il a s a m C., Chand a ragiri K.K., S a n k a ra n N. Allometric model for leaf area estimation in black pepper (Piper nigrum L.). J. Agron. Crop Sci., 2002, 188: 138-140.

21. U z u n S., Çe li k H. Leaf area prediction models (Uzçelik-I) for different horticultural plants. Turk. J. Agric. For., 1999, 23: 645-650.

22. M c K e e G.W. A soefficient for computing leaf area in hybrid corn. Agron. J., 1964, 56: 240-241.

23. Sazhin Yu.V., B a sova V.A. Mnogomernye statisticheskie metody [Multivariate statistical methods]. Moscow, 2002 (in Russ.).

24. Potapov V.A., B obrovich L.V., Polyanski i N.A., Andre eva N.V. Materialy Mezhdunarodnoi nauchno-metodicheskoi konferentsii [Proc. Science Methodol. Conf.]. Michurinsk, 1998: 28-31 (in Russ.).

25. Anik'ev A.A., Fedoryaka N.I., Pchelintsev S.A. Mezhdunarodnaya nauchnoprakticheskaya konferentsiya «Agropromyshlennyi kompleks: problemy i perspektivy» [Proc. Conf. «Agriculture: problems and prospects»]. Michurinsk, 2001, V. 3: 194-196 (in Russ.).

26. Markovskaya E.F., S y s o e va M.I., Trofi mova S.A., K u re t s V.K. Matematicheskie metody opredeleniya nekotorykh biometricheskikh pokazatelei u rastenii [Mathematical estimation of biometric parameters in plants]. Petrozavodsk, 1988 (in Russ.).

27. B o z h k o N.V. Vestnik sel'skokhozyaistvennoi nauki, 1973, 28(1): 21-22 (in Russ.).

28. B e r s o n G.Z., N a z a rova M.L. Fundamental'nye issledovaniya, 2008, 8: 60-61 (in Russ.).

29. Mois e i c he n k o V.F., Z ave ry u k h A.X., Trifo nova M.F. Osnovy nauchnykh issledovanii $v$ plodovodstve, ovoshchevodstve $i$ vinogradarstve [Basic research in horticulture, olericulture and viticulture]. Moscow, 1994: 130-133 (in Russ.). 